\title{
Small cell neuroendocrine carcinoma of uterine cervix with expressions of KIT, PDGFRA and bcl-2 and with long survival
}

\author{
Tadashi Terada * \\ Department of Pathology, Shizuoka City Shimizu Hospital, Shizuoka, Japan
}

Received: December 30, 2015

Accepted: March 9, 2016

Online Published: March 24, 2016

DOI: $10.5430 /$ crcp.v3n3p6

URL: http://dx.doi.org/10.5430/crcp.v3n3p6

\begin{abstract}
Primary small cell neuroendocrine carcinoma (SNEC) of uterine cervix is very rare; about 30 cases have been reported in literature. However, there have been no studies of KIT, PDGFRA, and bcl-2 in SNET of cervix. A 91-year-old woman presented vaginal bleeding which subsided by hemostatic drugs and balloon catheterization. Colposcopy showed a small tumor (6 mm) cervix and biopsy showed necrotic tissue and small atypical cells. They showed epithelioid features, small size, increased nucleo-cytoplasmic ratio, hyperchomatic nuclei, molded nuclei, scant cytoplasm, and absent nucleoli, thus fulfilling the criteria of SNEC of WHO. Immunohistochemically, tumor cells were positive for cytokeratin (CK) CAM5.2, CK AE1/3, CK7, CK8, CK18, CK19, NSE, synaptophysin, NCAM, KIT, PDGFRA, bcl-2, p53, and Ki-67 (labeling index $=100 \%$ ). The tumor cells were negative for CK5, CK6, CK34BE12, CK14, CK20, EMA, chromogranin, CD45, CD138, CD20, CD3, CD99 (MIC-2), vimentin, S100 protein, $\alpha$-smooth muscle actin, desmin, and myoglobin. Since neuroendocrine antigens (NSE, NCAM, synaptophysin, KIT and PDGFRA) were positive, a diagnosis of primary SNEC of cervix was made. Post-biopsy whole body studies revealed no other tumors. The patient rejected medical, surgical interventions because of very old age. She was followed-up, a mass of $5 \mathrm{~cm}$ was found in pelvic cavity. The patient is now alive 8 years after the diagnosis. The present case is the first of primary SNEC of cervix demonstrating positive KIT, PDGFRA, and bcl-2 proteins in a very old woman. The tumor was positive for many stem cells antigens, suggesting that the SNEC is a stem cell malignancy.
\end{abstract}

Key Words: Uterus, Cervix, Small cell neuroendocrine carcinoma, Neuroendocrine, KIT, PDGFRA, bcl-2

\section{INTRODUCTION}

Primary small cell neuroendocrine carcinoma (SNEC) of uterine cervix is very rare. At present, circa 30 cases of SNEC of cervix have been published. ${ }^{[1-12]}$ SNEC of endometrium is also extremely rare. ${ }^{[13-16]}$ However, there have been no studies on the status of KIT, platelet-derived growth factor receptor- $\alpha$ (PDGFRA), bcl-2 in these SNEC cases of female genital organs, except for one case of SNEC of endometrium, ${ }^{[17]}$ which showed expressions of KIT and PDGFRA but no mutations in these genes.

KIT and PDGFRA, both mapped to 4q12, encode transmembranous receptor tyrosine kinase oncoproteins called KIT (CD117) and PDGFRA, respectively. ${ }^{[18-23]}$ Both molecules are transmembranous oncoproteins involved in tumorigenesis, particularly in gastrointestinal stromal tumor (GIST), malignant melanoma, germ cell tumors, and hematopoietic

*Correspondence: Tadashi Terada; Email: piyo0111jp@yahoo.co.jp; Address: Department of Pathology, Shizuoka City Shimizu Hospital, Miyakami 1231 Shimizu-Ku, Shizuoka 424-8636, Japan. 
malignancies ${ }^{[18-23]}$ in which gene mutations of KIT and PDGFRA are frequently present. In general, SNEC of lung and extra-pulmonary locations shows KIT and PDGFRA proteins, but have no mutations of KIT and PDGFRA. Recently, bcl-2 expression in SNEC was reported, ${ }^{[24]}$ but no confirmative studies have been performed thereafter.

In general, SNEC of any locations shows very aggressive behaviors. Herein reported is a case of SNEC of cervix occurring in a 91-year-old woman with protein expressions of KIT, PDGFRA, and bcl-2. The patient shows relatively good prognosis, and is now alive for 8 years without treatment after the initial diagnosis.

\section{CASE REPORT}

A 91-year-old woman consulted our hospital because of vaginal bleeding. Blood and urine laboratory data shows no significant changes. A colposcopy and hysteroscopy showed a small tumor $(6 \mathrm{~mm})$ of UC, and a biopsy was made from it. The endometrium was free from changes, but a curettage biopsy was done. The bleeding subside after intake of hemostatic drug and next balloon catheterization. The biopsy of UC showed necrotic tissue and a few small atypical cells (see Figure 1A). The small cells showed epithelioid features, small size, increased nucleo-cytoplasmic ratio, hyperchomatic nuclei, molded nuclei, scant cytoplasm, and absent nucleoli (see Figure 1B). These feature fulfilled the criteria of small cell carcinoma of WHO blue book. The curettage of endometrium showed atrophic endometrium devoid of malignancy. The squamous epithelium seen in the biopsy showed koilocytosis, and serum study, which studied later, revealed HPV16.
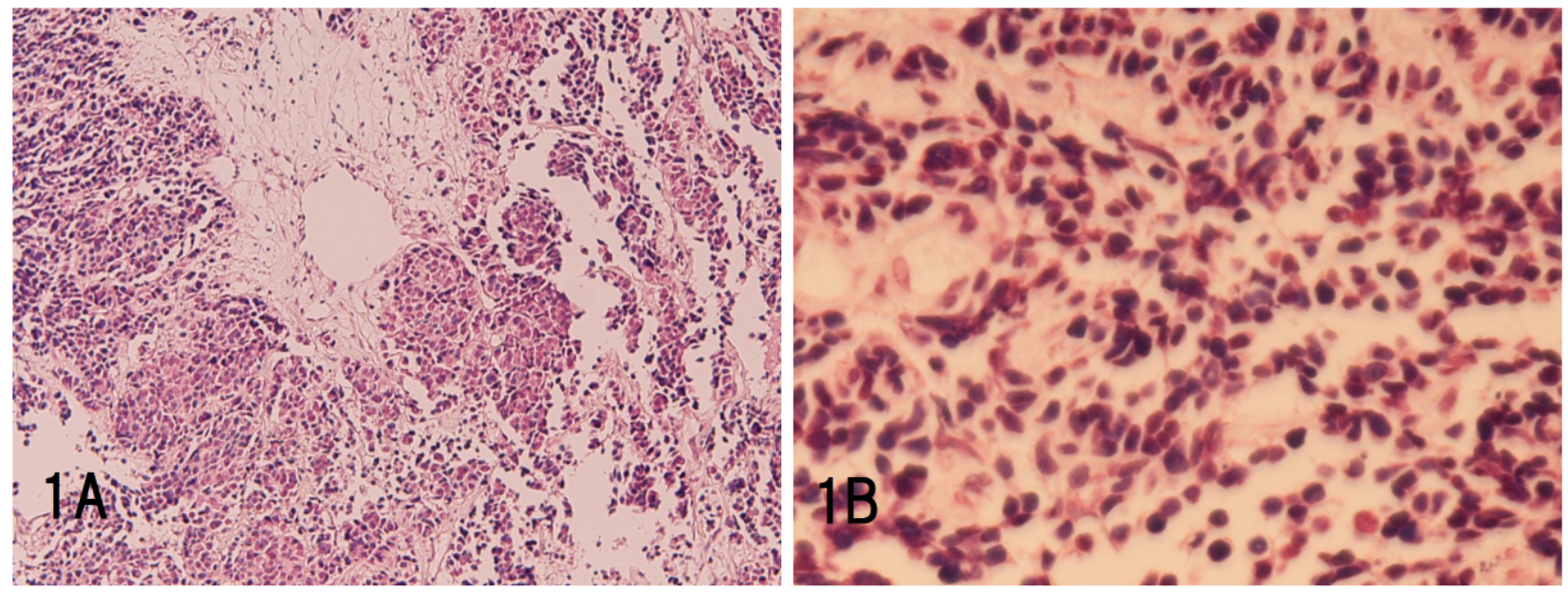

Figure 1. Histological features of uterine cervical small cell neuroendocrine carcinoma

A: Low power view. It shows necrosis and atypical malignant cells. $\times 40 ; B$ : High power view. The atypical cells showed small size, scant cytoplasm, increased nucleo-cytoplasmic ratio, hyperchromatic nuclei, molded nuclei, and absent nucleoli, all of which is characteristics of small cell neuroendocrine carcinoma. $H E, \times 200$.

An immunohistochemical study was done with the aid of Dako Envision method (Dako Corp, Glostrup, Denmark), as previously reported. ${ }^{[25,26]}$ Immunohistochemically, the tumor cells of UC were positive for cytokeratin (CK) CAM5.2, CK AE1/3, CK7, CK8 (see Figure 2A), CK18, CK19, NSE (see Figure 2B), synaptophysin, NCAM (CD56) (see Figure 2C), KIT (CD117) (see Figure 2D), PDGFRA (see Figure 2E), bcl-2 (see Figure 2F), p53, and Ki-67 (labeling index $=100 \%$ ). The tumor cells were negative for CK5, CK6, CK34BE12, CK14, CK20, EMA, chromogranin, CD45, CD138, CD20, CD3, CD99 (MIC-2), vimentin, S100 protein, $\alpha$-smooth muscle actin, desmin, and myoglobin. Because the tumor was difficult to diagnose and to strengthen the diagnosis, the anibody panel is relatively large.
Since neuroendocrine antigens (NSE, NCAM akaCD56, synaptophysin, KIT and PDGFRA) were positive and the cellular characteristics fulfilled the criteria of small cell carcinoma of WHO, ${ }^{[27]}$ a diagnosis of primary SNEC of cervix was made.

A molecular genetic analysis of KIT gene (exons 9, 11, 13, and 17) and PDGFRA gene (exons 12 and 18), performed by the PCR direct sequencing method as previously reported, ${ }^{[17-23]}$ revealed no mutations of exons of the genes of KIT (exons 9, 11, 13, and 17) and PDGFRA (exons 12 and 18) genes in this uterus tumor. Imatinib methylate (Gleevec) may, therefore, be ineffective.

Post-biopsy whole body imaging techniques and endoscopies 
of gastrointestinal tract revealed neither tumors nor lym- was found by images in the pelvic cavity. The patient is now phadenopathy. The patient refused operation and chemotherapy because of the very old age (91 years). She was followedup, and three years later, at 94 years of age, a mass of $5 \mathrm{~cm}$ alive 8 years after the diagnosis; the patient is now 99 years of age.
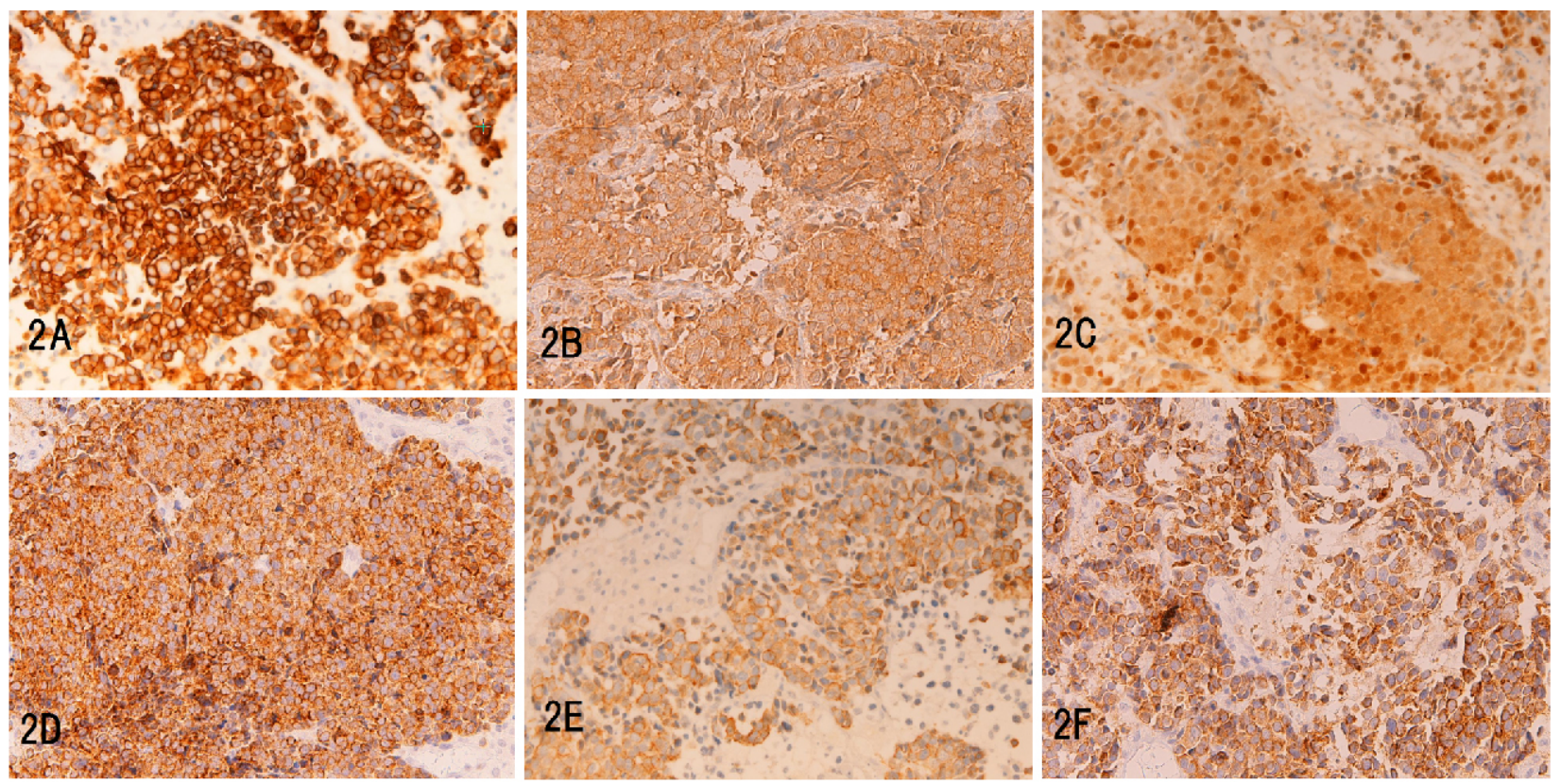

Figure 2. Immunohistochemical features of uterine cervical small cell neuroendocrine carcinoma. The tumor cells were positive for cytokeratin 8 (A), NSE (B), NCAM (C), KIT (D), PDGFRA (E), and bcl-2 (F). A-F: $\times 200$.

\section{Discussion}

Almost all malignant neoplasms in cervix is squamous cell carcinoma which is highly associated with HPV and cervical intraepithelial neoplasms (CIN). The second most common malignancy in this location is adenocarcinoma which shows aggressive course and may be associated with HPV and intraglandular neoplasms (IGN). ${ }^{[28,29]}$ Although the original cells of the present SNEC cervix are unclear, it is suspected that endocrine cells present in basal parts of cervix and basal cells are candidates for this tumor. Much more studies are needed to identify the original cells of SNEC of cervix.

It was now widely accepted that many kinds of tumors express KIT, the receptor of stem cell factor (SCF). KIT gene encodes transmembranous receptor tyrosine kinase oncoprotein. ${ }^{[17-23]}$ Many kinds of tumors express KIT. Of these, mutations of KIT and PDGFRA are frequently seen in GIST, e-GIST, malignant melanoma, germ cell tumors, and hematopoietic malignancies. However, most of other kinds of tumors with expressions of these two proteins are free from mutations of KIT and PDGFRA. The present SNEC was also devoid of the mutations. It is considered that if the gain-of-function mutations are present in KIT gene in a given tumor, imatinib methylate (Gleevec), a molecular drug targeting to KIT, may be effective. At present, imatinib methylate is effective only in GIST, the reason of which is unknown. Much more studies are necessary to create gene targeting drugs against KIT. KIT is also upregulated in tissue stem cells and cancer stem cells.

The strong and diffuse upregulations of bcl-2 is the second report in SNEC in the present report. The first was reported by LaPoint et al. ${ }^{[24]}$ who showed $100 \%$ (7/7) expression of bcl-2 in SNEC. The present case confirmed their findings. The reason for this expression is unclear, but it is considered that bcl-2 gene is activated, mutated or enhanced. The investigations of bcl-2 gene are needed. Thus, in addition to KIT, PDGFRA and other enuroendocrine antigens, bcl-2 may be among molecules or markers for SNEC. Bcl-2 is curious molecule; it is expressed in B-lymphocytes, in follicular lymphoma and in some mesenchymal tumors. Bcl-2 acts as an apoptosis inhibitor in carcinoma and in developmental biology. ${ }^{[30]}$ Thus, bcl-2 is among well markers of SNEC. More studies of bcl-2 and bcl-2 gene in SNEC of various organs are mandatory.

Furthermore, bcl-2 is well known to be among antigens or markers of stem cells (SC). KIT and PDGFRA, NSE, NCAM, synaptophysin, chromogranin, CK14, CD34 examined in the present study are well known antigens of SC. The present 
case was positive for NSE, synaptophysin, NCAM, KIT, PDGFRA, and bcl-2, all of which are well known SC antigens. As is well known, the $\mathrm{SC}$ have neuroendocrine features. These upregulations of SC antigens in the present tumor suggest that the present SNEC of cervix is a stem cell carcinoma or contains cancer SC. More studies of neuroendocrine tumor (NET) including NEC should be done under the concept of $\mathrm{SC}$ cancer.

Immunohistochemically, the present tumor showed a CK profile predominantly composed of low molecular weight CK. EMA was negative. Since SNEC histologically resemble malignant lymphoma and Ewing/PNET, the immunostainings of CK, vimentin, CD45, CD3, CD20, CD138, and CD99 are necessary for exclusion diagnosis, as seen in the present study. The neuroendocrine markers (NSE, NCAM aka CD56, synaptophysin and chromogranin) are necessary for making the diagnosis of neuroendocrine tumor. The KIT, PDGFRA and bcl-2 are much helpful in the diagnosis of SNEC. Other mesenchymal markers such as smooth muscle antigens and S100 protein are necessary to determine the diagnosis and evaluation of the mesenchymal differentiation. Immunostainings of p53 and Ki-67 can determine the malignant nature and the degree of malignant potentials. Immunostaining for lymphocyte markers is necessary for differentiation between lymphoma and small cell carcinoma.

Clinically, most of SNEC shows aggressive clinical course and the prognosis is not good, probably with median survival of circa 1 year. The present patient was very old woman (91 years of age), and survived eight years without therapy. The patient is now alive without any treatments eight years after the diagnosis; the patient is now 99 years of age, though the patient has now a pelvic mass probably of metastasis. Among patients with primary SNEC of various organs, the present patient seems to be among the oldest persons and the longest survivors. The longevity of life expectancy is only speculative in this patient without medical and surgical intervensions. It is partly due to the small size, only $6 \mathrm{~mm}$ in cervix at a very early stage: Stage 1 . This may reflect low aggressive nature of the tumor. In considering the size and stage of the tumor, the present case can correspond to tumorets of lung, another neuroendocrine lung tumor. The early stage and small size can be responsible for the well survival. As is often the case in any cancers, the survival has scattering: a significant percentage show poorest and in contrary good prognosis. The author experienced recently a patient with paranasal SNEC who lived more than 10 years after the SCNEC diagnosis. In fact, small cell carcinoma can show relatively good prognosis. ${ }^{[31]}$

In summary, the author reported a very rare case of SNEC of uterine cervix. The histology was considered relatively typical. Immunohistochemically, the tumor was carcinoma with neuroendocrine features and positivity of KIT, PDGFRA and bcl-2. The tumors were positive for many stem cells antigens, suggesting that SNEC is a stem cell malignancy. The genetics showed no mutations of KIT and PDGFRA genes. Clinically, the patient was characterized by very old age and long survival without treatments.

\section{CONFlicts OF InTEREST Disclosure}

The author declares no conflict of interest.

\section{REFERENCES}

[1] Niu X, Gilbert L. Neuroendocrine carcinoma of the uterine cervix: a single institution case review. Eur J Gynaecol Oncol. 2011; 32: 377-80. PMid: 21941956.

[2] Watanabe Y, Nakai H, Imaoka I, et al. Carcinomatous meningitis during systematic chemotherapy in a patient with advanced small-cell neuroendocrine carcinoma of the uterine cervix. J Obstet Gynaecol Res. 2012; 38: 336-9. PMid: 21917069. http: //dx.doi.org/10.1111/j.1447-0756.2011.01634.x

[3] Reig CA, Membrive CI, Foro AP, et al. Neuroendocrine small cell carcinoma of the uterine cervix. Clin Transl Oncol. 2010; 12: 5123. PMid: 20615830. http://dx.doi.org/10.1007/s12094-0 10-0546-0

[4] Ota T, Kitano T, Miyai K, et al. Small cell carcinoma of the uterine cervix metastasizing to the bone marrow: a case report. J Obstet Gynaecol Res. 2008; 34: 692-5. PMid: 18840183. http: //dx.doi.org/10.1111/j.1447-0756.2008.00731.x

[5] Kim MJ, Kim NR, Cho HY, et al. Differential diagnostic features of small cell carcinoma in the uterine cervix. Diagn Cytopathol. 2008;
36: 618-23. PMid: 18677758. http://dx.doi.org/10.1002/dc. 20875

[6] Korcum AF, Aksu G, Bozcuk H, et al. Small cell carcinoma of the cervix: a case report. Arch Gynecol Obstet. 2008; 277: $367-$ 70. PMid: 17828547 . http://dx.doi.org/10.1007/s00404-0 07-0463-9

[7] Alphandery C, Dagrada G, Frattini M, et al. Neuroendocrine small cell carcinoma of the cervix associated with endocervical adenocarcinoma: a case report. Acta Cytol. 2007; 51: 589-93. PMid: 17718130 http://dx.doi.org/10.1159/000325803

[8] Wang KL, Yang YC, Wang TY, et al. Neuroendocrine carcinoma of the uterine cervix: A clinicopathologic retrospective study of 31 cases with prognostic implications. J Chemother. 2006; 18: 209-16. PMid: 16736891. http://dx.doi.org/10.1179/joc.2006.18 .2 .209

[9] Watanabe A, Wachi T, Omi H, et al. Granulocyte colonystimulating factor-producing small-cell carcinoma of the uterine cervix: report of a case. Diagn Cytopathol. 2000; 23: 
269-74. http://dx.doi.org/10.1002/1097-0339(200010)2

3:4<269:: AID-DC11>3.0.CO;2-A

[10] Proca DM, Hitchcock CL, Keyhani-Rofagha S. Exfoliative cytology of lymphoepitheliomalike carcinoma of the uterine cervix. A report of two cases. Acta Cytol. 2000; 44: 410-4. PMid: 10834001. http://dx.doi.org/10.1159/000328488

[11] Zhou C, Hayes MM, Clement PB, et al. Small cell carcinoma of the uterine cervix: cytologic findings in 13 cases. Cancer 1998; 84: 281-8. http://dx.doi.org/10.1002/(SICI) 1097-0 142 (19981025) $84: 5<281:$ : AID-CNCR3>3 . 0 . CO ; $2-W$

[12] Tsou MH, Tan TD, Cheng SH, et al. Small cell carcinoma of the uterine cervix with large cell neuroendocrine carcinoma component. Gynecol Oncol. 1998; 68: 69-72. PMid: 9454664. http: //dx.doi.org/10.1006/gyno.1997.4899

[13] Huntsman DG, Clements PB, Gilks CB, et al. Small-cell carcinoma of the endometrium. A clinicopathological study of sixtenn cases. Am J Surg Pathol. 1994; 18: 364-75. PMid: 7511354. http://dx.doi.org/10.1097/00000478-199404000-00005

[14] van HKH, Hudock JA, Woodruff JM, et al. Small cell neuroendocrine carcinoma of the endometrium. Int J Gynecol Pathol. 1995; 14: 21-9. PMid: 7883422. http://dx.doi.org/10.1097/00004347-199 501000-00005

[15] Varras M, Akrivis Ch, Demou A, et al. Primary small-cell carcinoma of the endometrium: clinicopathologic study of a case and review of the literature. Eur J Gynecol Oncol. 2002; 23: 577-81. PMid: 12556112 .

[16] Albores-Saavedra J, Martinez-Benitez B, Luevano E. Small cell carcinomas and large cell neuroendocrine carcinomas of the endometrium and cervix: polypoid tumors and those arising in polyps may have a favorable prognosis. Int J Gynecol Pathol. 2008; 27: 333-9. PMid: 18580310. http://dx.doi.org/10.1097/PGP.0 b013e31815de006

[17] Terada T. KIT-positive primary small cell carcinoma of the endometrium: a case report with immunohistochemical and molecular genetic analysis of KIT and PDGFRA genes. Arch Gynecol Obstet. 2010; 282: 413-6. PMid: 20035340. http://dx.doi .org/10.10 07/s00404-009-1324-5

[18] Terada T. Small cell neuroendocrine carcinoma of the prostate: Incidence and a report of four cases with an examination of KIT and PDGFRA. Prostate. 2012; 72: 1150-6. PMid: 22127977. http: $/ / \mathrm{dx}$.doi.org/10.1002/pros. 22464

[19] Terada T. KIT and PDGFRA in esophageal pure small cell carcinoma. Int J Clin Exp Pathol. 2011; 4: 718-21. PMid: 22076173.

[20] http://dx.doi.org/10.1186/1472-6963-13-502
[21] Terada T. Mutations and protein expression of KIT and PDGFRA genes in ipsilateral testicular seminomas: an immunohistochemical and molecular genetic study. Appl Immunohistochem Mol Morphol. 2011; 19: 450-3. PMid: 21403518. http://dx.doi.org/10.10 97/PAI . Ob013e31820d2872

[22] Terada T. Low incidence of KIT gene mutations and no PDGFRA gene mutations in primary cutaneous melanoma: an immunohistochemical and molecular genetic study of Japanese cases. Int J Clin Oncol. 2010; 15: 453-6. PMid: 20425130. http://dx.doi.org/1 $0.1007 / \mathrm{s} 10147-010-0087-0$

[23] Terada T. Mediastinal seminoma with multiple KIT gene mutations. Pathology. 2009; 41: 695-7. PMid: 20001354. http://dx.doi.o $\mathrm{rg} / 10.3109 / 00313020903305852$

[24] LaPoint RJ, Bourne PA, Wang HL, et al. Coexpression of c-kit and bcl-2 in small cell carcinoma and large cell neuroendocrine carcinoma of the lung. Appl Immunohistochem Mol Morphol. 2007; 15: 401-6. PMid: 18091382. http://dx.doi.org/10.1097/01.pai. $0000213153.41440 .7 \mathrm{~d}$

[25] Terada T, Kawaguchi M, Furukawa K, et al. Minute mixed ductalendocrine carcinoma of the pancreas with predominant intraductal growth. Pathol Int. 2002; 52: 740-6. PMid: 12685552. http: //dx.doi.org/10.1046/j.1440-1827.2002.01416.x

[26] Terada T, Takeuchi T, Taniguchi M. Hepatobiliary cystadenocarcinoma with cystadenoma elements of the gall bladder in an old man. Pathol Int. 2003; 53: 790-5. PMid: 14629305. http://dx.doi.o $\mathrm{rg} / 10.1046 / \mathrm{j} .1440-1827.2003 .01559 . \mathrm{x}$

[27] Travis W, Nicholson S, Hirsch FR, et al. Small cell carcinoma. In: Travis WD, Blambillia E, Muller-Hermelink K, Harris CC eds. WHO classification of tumour. Pathology and genetics of tumours of the lung pleura, thymus and heart. IARC press, Lyon, 2004. p31-4.

[28] Terada T. Coexistence of early microinvasive endometrioid adenocarcinoma and CIN3 in the uterine cervix in a 32-year-old Japanese woman. Diagn Pathol. 2011; 6: 51. PMid: 21663603. http://dx.doi.org/10.1186/1746-1596-6-51

[29] Terada T. Simultaneous squamous cell carcinoma in situ and adenocarcinoma in situ of the uterine cervix in a 36-year-old Japanese woman. Arch Gynecol Obstet. 2010 ; 281: 527-30. PMid: 19693522. http://dx.doi.org/10.1007/s00404-009-1208-8

[30] Terada T, Nakanuma Y. Detection of apoptosis and expression of apoptosis-related proteins during human intrahepatic bile duct development. Am J Pathol. 1995; 146: 67-74. PMid: 7531950.

[31] Ikeda S, Takabe K, Inagaki M, et al. Expression of phosphorylated Akt in patients with small cell carcinoma of the lung indicates good prognosis. Pathol Int. 2010; 60: 714-9. PMid: 20946520. http://dx.doi.org/10.1111/j.1440-1827.2010.02594.x 